\title{
THE ZAKAT REFORM AND MANAGEMENT OF ZAKAT IN INDONESIA
}

\section{ENDING SOLEHUDIN M. AG}

Lecturer of Syariah Faculty of UIN Sunan Gunung Djati Bandung West Java Indonesia

\section{ABSTRACT}

This study aims to analyse and formulate: (1) Urgency fatwa in zakat legal reform in Indonesia; (2) The nature of fatwas and methods of determining the fatwa of Islamic mass organizations; (3) Contributions of fatwas, against the legal reform of zakat; (4) the zakat reform law in the fatwa of Islamic mass organizations; (5) Application of zakat law in Indonesian society; (7) Compatibility of zakat legal reform in the fatwa of mass organizations, concerning zakat management; The theoretical framework used in this research is: Grand Theory, the theory of maqashid alsyari ah that the law of ijtihad result must be in accordance with al-syari's aims. Middle range theory, legal system theory (legal system), that law is a unity system consisting of elements: substance, structure and culture. Applied theory, ijtihad theory and theory of law substance. The theory of ijtihad, that new legal product can be formulated through the process of ijtihad. Theory of legal substance, which the substance of the law must be in harmony with the rules of other laws either vertically or horizontally.

This research uses analytical descriptive method. While the approach uses a normative juridical approach. Primary data sources in this study are: fatwa about zakat issued by Majelis Tarjih Muhammadiyah on the Management of Zakat. The secondary data sources are books for analysing and interpreting primary data.

From the results of the study can be concluded: (1) Fatwa has a very urgent position to answer various contemporary legal issues about zakat; (2) The fatwa is essentially a legal opinion, conveyed by the 'ulama, established through the process of ijtihad in response to the matter conveyed to him; (3) The fatwa of mass organizations contributes significantly to the development of zakat law in Indonesia (4) Zakat legal reform in the fatwa a.l.: zakat saving, deposits, demand deposits, zakat crops other than rice, zakat fishery, zakat for productive business and zakat management through investment (5) the zakat reform in Legal a.l.: zakat of legal entity, zakat on money and securities, forestry, fishery, industry, income and services, and zakat for productive enterprise (article 27); (6) Sociologically, every Muslim accepts the authority of Islamic law and obeys his shari'at, including the shari'at of zakat, but the degree is different from each other depending on his piety, in accordance with the theory of credo or shahadah and the nonterritoriality theory of Shafi'i states, that a Muslim is forever bound to implement Islamic law, wherever he is; (7) In general, there is an agreement between the zakat reform law, contained in the fatwa of Islamic mass organizations, in Indonesia.

KEYWORDS: Reform, Legal/Law \& Management of Zakat

Received: Oct 09, 2017; Accepted: Oct 29, 2017; Published: Nov 15, 2017; Paper Id.: IJPSLIRDEC20172

\section{INTRODUCTION}

Zakat is one of the main pillars of Islamic teachings. He occupies the 3rd position, in the order of Pillars of Islam, that is after the shahadah and prays (Shahih Bukhari, 1981: 8). This position brings the consequences of zakat law, as a fundamental duty of Islamic teachings, that is parallel to prayer, the $s a w m^{* 1)}$ and hajj. The position indicates that, the obligation of tithe is part of the dharuri religious teachings of Islam ( $\mathrm{ma}^{\prime l u m} \mathrm{~min}$ al-din bi al- 
dharurah) and becomes an indicator of a person's religion. It is a dharuri duty and self-attachment (iltizam bi nafsih) to every Muslim individual, who has property to a predetermined limit (nishab).

The legal status of zakat in the law (shari'at) of Islam is very solid, because it is based on the qath'i proofs, both in the Qur'an and al-Sunnah. According to Abbas Kararah the word zakat, with its various derivations is mentioned in the Qur'an 82 times (Abbas Kararah, 1956: 60), and in 27 versus the word zakat is expressed simultaneously, with the command of prayer in various sentence contexts (Yusuf al- Qardlawi, 1991: 42).

Similarly in al-Sunnah, in the Pole of al-Sittah for example, there are about 564 hadiths concerning zakat. So strong is the position of this zakat law, that its existence is considered ma'lum min al-dien bi al-dharurah or known automatically and is an absolute part of Islam, for someone (Ibid: 231).

Discussion of zakat in books of fiqh, included into the chapters of worship, and positioned after the discussion of prayer, thus the zakat belongs to the group of jurisprudence. If prayers, the sawm and pilgrims are inserted into the category of worship nafsiyah, then zakat is included in the category of maliyah ijtima'iyah (ibid: 235), called maliyah worship because zakat worship relates specifically to property ownership, namely the obligation to exclude part of the property belongs to every Muslim, who has attained nisab. It is called ijtima'iyah worship because, the zakat worship is directly related to the development of the economic welfare of the community, both in the effort to sponsor the faqir and the poor, as well as in the development of social institutions such as $d a^{\prime} w a h$, education, and other social welfare.

Zakat can be entered into the category of fiqh muamalat, if muamalat is defined as the relationship between man and man in the public sphere, regarding material rights (ownership rights, tenure rights, concession rights, use rights, and the right of transfer of property). Thus, zakat can be grouped into the muamalat field they are: the distribution of surplus value of a thing or something, that can be valued objects (money and service products), owned by muzaki to some groups in public life (mustahiq), according to the content nisab, haul and their respective proportions (Cik Hasan Bisri, 2003: 345346). However, the categorization of zakat into fiqi muamalat is not common and not found, in the books of fiqh.

As worship maliyah ijtima'iyyah then zakat is an important part of Islamic social. The zakat has enormous potential for the development of social welfare, health, economy, da'wah, education, even defense and state security. The huge potential of zakat will be actualized effectively and efficiently, if zakat is managed with good rules.

History has proved that the economic and political stability of the government during the time of the Prophet in Medina was largely supported by zakat funds managed effectively and efficiently, in addition to other sources of income, such as ghanimah, fai and jizyah. At that time zakat is the most important state income with budget allocation devoted to poverty alleviation and social welfare (faqir, poor, gharimin and ibn sabil), employment (amilin), education and da'wah, as well as security of state (mu allaf and sabilillah). Similarly, during the reign of Khulafa al-Rashidin, the contribution of zakat to state revenues and expenditures still occupy the most important position, as a source of state income (Abdul Wahab khalaf, 1977: 114).

In the study of fiqh jurisprudence, zakat is distinguished from infaq and shadaqah, if shadaqah is interpreted as any form of expenditure of good property, which is obligatory or the sunnah, then infaq is interpreted as a form of expenditure of the obligatory legal property. What distinguishes zakat from infaq is the infaq, not specified the type of property, nisab, the level of property expended, as well as the parties, who are entitled to get his share. Zakat, on the contrary, is a form of expenditure of property whose law is obligatory, if it meets the provisions of nishab, with a 
predetermined level and intended for certain mustahik. In shadaqah and infaq not specifically described the types of property that is issued, the zakah on the types of property that must be zoned has been described in detail (Dede Rosyada, 1999: 109).

Zakat is also divided into two categories namely Zakat al-Fitr and zakat al-Mal (wealth). Zakat al-Fitr is seen as zakat al-nafs which must be issued by individuals, without distinguished who have baligh and who have not baligh. So the obligation to issue Zakat al-Fitr is applicable to all Muslim individuals since the newborn baby before setting eyes on the last day of the month of Ramadan, to old elderly people who have udzur. It's just that this duty is imposed on the person in charge of the family, not the individual (Abi Abdillah Muhammad bin Abdi al-Rahmah, 1996: 62-63). As worship attendant the sawm Ramadan Zakat al-Fitr is also seen as a perfect worship the sawm and other worship, in order to live the holy month of Ramadan (qiyamal-Ramadhan). In a hadith it is stated that, one's Ramadan the sawm worship will depend on between heaven and earth (mudabdabun baina al-sama' wa al-ardh) and will not be accepted by Allah, until his Zakat al-Fitr is paid.

While zakat al-Mal is an obligatory expenditure, on the possession of property that has reached nishab, the types of property that must be zoned zakat has been determined by syara' the good nisab', haul and zakat levels. Among the types of zakah required in the books of al-Fiqh classical jurisprudence, they are: (1) gold and silver, (2) money as saving, (3) all kinds of agricultural produce (zira `ah), (4) all types of mine products (ma`din), (5) livestock (camels, cows and goats), (6) trade goods (tijarah), and (7) findings / treasure (rikaz). There is almost no difference, between the scholars and the madhhab priests (Sahal Mahfudh, 2011: 150). One of the fatwa institutions, that are concerned, with the charity of this institution is the Majelis Tarjih Muhammadiyah. The presence of a fatwa, on the zakat of this institution is not without criticism, some scholars highlight the weakness of this fatwa, from the aspect of the legal subject, which in the study of fiqh is known as mukallaf. In this case, the mukallaf is the one who has been subjected to the burden of the law (taklif), that is, the man who has been balig and sensible. No mukallaf other than humans, including legal entities cannot be categorized as mukallaf. For the enforcement of the law, in the shar'i related to the actions of individuals, in the framework of obedience or disobedience to the commandments and prohibitions of God, that resulted in rewards and sin.

With this rationale, arises the question, the obligation of zakat this institution is the act of charity who? To whose reward is given if the obligation is obeyed? And who will bear his sin if the duty is denied? Not to mention that the ownership of the company's shares is certainly not only Muslims, but also non-Muslims. Whereas, the legal of taklif syariat is only charged to the Muslims, not to non-Muslims.

The zakat issue of this institution is increasingly complex, with the emergence of critical questions about its application. For example, if a company's zakat has been issued, is the stockholder of the company still liable with the zakat liability of the share gain it earns? If the answer 'yes' means there is twice the obligation of zakat from the same source of income.

Another question immediately followed, whether the calculation of nisab zakat companies or institutions is calculated from total assets, total capital, total gross profit (gross profit), or from total net income? It is not easy to parse the issues surrounding the zakat of this institution, it requires a serious study.

And the other issues emerging around this contemporary zakat study are the presence of various forms of innovation and variations of zakat distribution, the expansion of meaning of mustahiq groups, and the development of 
productive zakat as an alternative to long-term programmable economic and programmed poverty empowerment.

Among other things, the use of zakat funds, for the construction of hospitals, the procurement of ambulance and health facilities, educational facilities, public transportation facilities for the poor, maternity expenses, medical expenses, education costs, granting revolving capital known as productive zakat and so forth. This is like what is now intensively done by some zakat management institutions such, as Rumah Zakat, Dompet Dhuafa Republika, and so forth.

These fatwas became one of the sources of legal and basic reference, for the drafting of the Zakat Management Act, especially in appreciating and accommodating new developments in zakat legal thought, whether related to the addition of the zakat property variant, the nishab, the haul and the zakat level, the development of asnaf-asnaf mustahiq interpretation, as well as related to management and distribution management. However, some fatwas that were born after the enactment of the Act, certainly not accommodated in it. These fatwas remain the legal instruments, used by zakat agencies and institutions, as the legal basis for developing various management policies for zakat management. For example fatwas for the use of zakat for scholarships, free ambulances, maternity hospitals and so forth.

Therefore, the existence of Islamic fatwas about zakat is still needed, as a legal basis for the implementation of zakat which has no legal provisions in the Law of Zakat Management and in fiqh classical. The legal position of the clerical fatwas has the same strength as the figh and the Law, which is used as the legal basis in the management of zakat. As the fatwa-fatwa of the National Sharia Council (DSN), which is used as the operational legal basis for sharia financial institutions (banks and non-banks), both before and after the birth of the Islamic Banking Law.

The constitution No. 38 of 1999 on the Management of Zakat can be recognized, as a qualitative progress of the implementation of zakat in Indonesia. This law gives legitimacy power to religious institutions, as well as a form of government concern in managing the management of zakat. However, it does not mean that before the Law no. 38, zakat as the welfare fund of the ummah, not executed. This Act is actually born as the culmination of the process of struggle of ulama and the parties concerned, with the management of zakat, whose embryo has grown widely.

In 1968 the Agency for Amil Zakat Infaq and Shadaqah (BAZIS) has been established in DKI Jakarta. In that same year, the government through the Minister of Religious Affairs issued a Regulation of the Minister of Religious Affairs (PMA) No. 4 of 1968 dated July 15, 1968 on the Establishment of Amil Zakat Body. Then Regulation of the Minister of Religious Affairs No. 5 of 1968 On October 22, 1968 on the Establishment of Baitul Mal at the central, provincial and municipal levels.

Implementation and management of zakat continues, to be implemented by several organizations or Badan Amil Zakat (BAZ) or the Zakat Institution, established on the initiative of religious and civic leaders supported by the local government, although without formal regulation by law by the state. This certainly has implications for the results of the efforts of the agency or zakat institution that has not been felt significantly, by the wider community (Ibid: 62).

Management system of zakat, infaq and shadaqah management is run independently, by each agency, between the Zakat Institution one with other the Zakat Institution, there is no system uniformity. This is indicated by the results of a study that found the conclusion that, the role of zakat institution varies with the following variations: First, institutions that only arrive at the level of zakat al-Fitr only, as did by the Zakat Institution in West Java; Secondly, the institution is more focused on collecting zakat al-mal (wealth), plus the collection of shadaqah and infaq, as done by the Zakat Institution of Jakarta (BAZIS DKI); Third, the institution that collects all kinds of virtues in Islam, in it not only collect zakat, infaq and 
shadaqah, but also includes waqaf, grants, and so forth. The institution that runs this third model function calls itself the baitul mal.

The Zakat Institution has different management systems and has not been well organized, was mentioned by President Soeharto in a speech at the Isra Mi'raj memorial ceremony, at the State Palace on October 22, 1968. Personally, President Soeharto issued a suggestion, to collect zakat systematically and organized. This suggestion is not legally binding, but has had an effect, on the discourse of thinking about the management of zakat, from what was originally seen as a matter of religion or the internal affairs of Muslims, and then, leads to the possibility of being accommodated by the government as a state matter (Ibid). The management of zakat as a state issue was increasingly accommodated and accepted, during the reign of B. J. Habibie. The management of zakat receives serious attention from the Government; the legal protection of the implementation of zakat is seen as the manifestation of the state to guarantee the independence of each citizen, to worship according to their respective religion. In addition, zakat is seen as the economic potential of the community that can improve the welfare of the community (Constitution No. 38, 1999), therefore it is necessary to make its own rules.

The operational definition of the title of the study can be briefly described as follows: reform, the intention is to change from the old concept to the new concept, both changes in legal provisions and changes in the management mechanism. The Reform (Indonesian: Pembaruan) could be the development of an existing concept, based on the source (عموم اللفظ). It could also be the addition of new variants, new concepts, or new legal provisions, previously nonexistent, based on the meaning (عموم المعنى) of existing concepts. The Legal, referred to in this title, encompasses all the provisions of the figh and the fatwas relating to the rules of zakat, and the law on the management of zakat. The Management is the procedure of acceptance or collection, calculation, distribution / allocation, distribution and utilization of zakat. The Zakat is part of the property or asset, which must be issued by muzaki, who has reached nishab with certain conditions and distributed to mustahiq, which have been determined. The fatwa is the legal opinion of the result of ijti had proposed by the mufti or the fatwa institution, concerning a particular matter as an answer to the question posed to it, or as a legal answer to the problems occurring in society. Islamic mass organization, in the title of this dissertation is the institution of fatwa of Islamic mass organization, which is limited to 2 institutions, namely: Majelis Tarjih Muhammadiyah, and Majelis Bahtsul Masa'il Nahdhatul Ulama (NU), about the Management of Zakat.

\section{LITERATURE REVIEW}

\section{METHODOLOGY}

The method used in this research is the normative juridical method. Implementation of this normative juridical method is to conduct analysis and interpretation of texts fatwa Islamic mass organizations and texts, used as a back and source of reference, by the scholars and contemporary faqih (plural Fuqahā), in formulating and establishing fatwas about the zakat. Further, analyzing and interpreting the articles in the Act on the management of zakat, to be revealed in accordance with the theory used, namely the theory of maqashid al-syari ah, the theory of legal systems and the theory of ijtihad. Method of data analysis to be conducted in this research is normative-interpretative analysis, with stages as follows:

- Collected data is classified according to data type and problem area;

- After the next classification is done interpretation based on theories used, namely the theory of maqashid al- 
syari ah, the theory of legal systems and the theory of ijtihad;

- The results of interpretation of primary and secondary data, then connected with the formulation of the problems studied;

- After obtained the intersection between the data, interpretation of data and the formulation of the problem then compiled into systematics that have been made;

- $\quad$ Last done withdrawal conclusion.

\section{RESULT AND DISCUSSIONS \\ RESULT}

The results can be concluded: (1) Fatwa has a very urgent position to answer various contemporary legal problems about zakat; (2) The fatwa is essentially a legal opinion conveyed by the 'ulama, established, through the process of ijtihad in response to the matter conveyed to him; (3) The fatwa of mass organizations contributes significantly, to the development of zakat law in Indonesia (4) Renewal of zakat law in fatwa al: zakat saving, deposits, demand deposits, zakat crops other than rice, zakat fishery, zakat for productive business and zakat management through investment (5 ) renewal of zakat in the Law al: zakat of legal entity, zakat on money and securities, forestry, fishery, industry, income and services, and zakat for productive enterprise (article 27); (6) Sociologically, every Muslim accepts the authority of Islamic law and obeys his sharia, including the sharia of zakat, but the degree is different from each other, depending on his piety, in accordance with the theory of credo or shahadah and the non-territoriality theory of Shafi'i states that, a Muslim is forever bound to implement Islamic law wherever he is; (7) In general there is an agreement between the renewal of zakat law, contained in the fatwa of Islamic mass organizations, in Indonesia.

The fatwa has a very urgent role, in the reform of zakat law in Indonesia, because although the provisions of zakat law are set in detail, in the texts of the Qur'an and al-Sunnah, but in line with the ever-changing social life, the demand for renewal of zakat law is inevitable from time to time. This is in accordance with the rule which states: "Nash (al-Qur'an and al-Hadith) has ceased to fall, while events / problems in society will not cease" (النصوص مناهية و الو اقائع غير مناهية). To answer new issues about zakat, can only be done through a fatwa, established by scholars or institutions that are competent and reliable.

In the essence a fatwa is a legal opinion (legal pinion), submitted by scholars both individuals and groups, who are members of the fatwa institution, which is established through the process of ijtihad, in response to the problems conveyed to him. The method of ijtihad conducted by the Muhammadiyah Tarjih Council, tends to use the contextual interpretation of the texts and logical reasoning, based on the consideration of benefit (al-burhani wa al-istishlahi). The method of ijtihad conducted by the NU's Majelis Bahtsul Masa, tended to restore the problem to the opinions of earlier scholars, in the books of mu'tabarah (ittiba al-madzhab) and in responding to new problems not found in the poles of al-mu'tabarah, the fatwa is established through ijtihad, according to the method of ijtihad ulama Shafi iyah (ittiba`al-manhaj). The method of ijtihad by Dewan Hisbah Persatuan Islam tends to return the question to the Qur'an and al-Sunnah, through textual interpretation (istidlal).

There are new legal thoughts contained, in the fatwas of the good zakat issued by: Majelis Tarjih Muhammadiyah, and Majelis Bahtsul Masa'il Nahdhatul Ulama (NU). These fatwas make an important contribution to the development of 
zakat law in Indonesia, both at the discourse level, at the application level. The application of zakat law in Indonesian society is manifested, as stated in the theory of legal authority, i.e. that, if a Muslim has accepted Islam as his religion he will receive the authority of Islamic law to him. Thus, sociologically, people who embrace Islam will accept the authority of Islamic law and obey, in the implementation of Islamic law, including syari at about zakat. But, this obedience will be different from each other because, it depends on the level of piety of each. This is also in accordance with the theory of credo or creed, which requires the implementation of Islamic law, by those who have uttered Kalima Shahadat, as a logical consequence of the pronunciation of his credo. Similarly, the non-territorial theory of Imam Shafi'i states that, a Muslim is forever bound to implement Islamic law wherever he is.

\section{DISCUSSIONS}

\section{The Definition of Pembaruan}

Great Dictionary of the Indonesian Language (Indonesian: Kamus Besar Bahasa Indonesia), defines the word ofpembaruan (reform) as the process, the way, the act of updating. Renewing itself according to KBBI means (1) to improve to become new, (2) repeat once again, start again and (3) replace with new, modify (Depdiknas, 2005: 109). When associated with the word "law" a phrase will appear: the process of enforcing legal reform, by means of fixing, modifying, or replacing with a new one.

In Arabic the reform is a translation of the word tajdid. Abdul Manan, professor of law and former judge, in the book The Law-Changing Aspect, explains at length about the notion of tajdid, based on accurate sources. The term tajdid terminology based on Muhammadiyah is also described in length by Rifyal Ka ‘bah, professor of law and former judge in his book Islamic Law, in Indonesia. Based on the understanding given by Muhammadiyah, Rifyal Ka`bah concluded that, the legal reform according to Muhammadiyah is a combination of tajdid and ijtihad (Rifyal Ka'bah, 1999: 115).

The others use terms for legal reform. According to Satjipto Rahardjo, there are those who use the terms of legal development, legal change, legal coaching, or legal modernization. Finally, many also use the term law reform, which is a translation of legal reform. Despite the various terms used, Satjipto agrees with Sudargo Gautama, to use the term law renewal, since the term is closer to describing how to set up a legal order that adapts to changes that occur in society (Satjipto Rahardjo, 2009: 15).

\section{Legal Reform According to the Jurist}

Most the Jurists agree that, the law (always) requires an reform. This happens because society is always changing, not static. According to (Satjipto Rahardjo, 2000: 190), changes occurring in people's lives can be categorized into two categories: 1. Slow, incremental change, gradually increasing; 2. Changes in a large scale, revolutionary change. Against the slow change of adaptation between law and society is enough, to make small changes to the existing regulatory order, either by changing or adding it. Methods of legal interpretation and legal construction also include, equipment to adapt to large scale changes. Another problem, when the change is large, the reform with a small way like the above is no longer possible enough, to overcome them. Adjustments must be made in a revolutionary manner, as adopted by European countries, when they choose civilization civilizations.

Soetandyo Wignjosoebroto in an article entitled "Legal Renewal of the New Indonesian Society", distinguishes legal reform in the legal sense, with legal reform in the sense of law reform. Legal reform in the sense of legal reform is for the society, where law is only a subsystem and serves as a tool of social engineering solely. Law only becomes part of a 
political process, that may also be progressive and reformative (Soetandyo Wignjosoebroto, 2007: 94).

The legal reform in this study only means as the constitution reform. As a political process Soetandyo states that, legal reform involves only the thinking of politicians, or a few professional elites, who have lobbying access. Indonesia according to Soeytandyo, falls into this category. This is different from legal reform, in the sense of law reform. In this form the law is not the business of judges and other law enforcers, but also of public affairs in general. It may have been made in the form of law, but the law is not sacred above all else. In this concept of law is the product of a sovereign people's political activity, driven by the sovereign interests of the people, who may be inspired by the economic, social, or ideal values of the culture of the people themselves.

The definition of law reform according to Soetandyo Wignjosoebroto, can be attributed to the Constitution Number 48 of 2009 Article 5, Section 1, About Judicial Power. This Article mandates the judge to explore, follow, and understand the legal values and sense of justice, living in the community. The phrase of digging, following, and understanding means that the legal values, are not yet visible on the surface, strictly not contained in the legislation.

Abdul Manan, explains there are two dominant views related to change (of course in the sense of reform) of the law that applies in the life of society in a country, namely the traditional view and the modern view. In the traditional view, the society must change before the new law comes to regulate it. On the other hand, in the modern view, in order for the law to accommodate all new developments, the law must always coincide with the events (Abdul Manan, 2005: 7). In the field of neutral law changes should be aimed at giving birth to a legal certainty, otherwise in the field of personal life, the law must serve as a means of social control in the life of society.

\section{Legal Reform in the National Politic Law}

Mahfud MD, (2001: 11) presents two ways to find out the form of the National Political Law (NPL). From a formal perspective, PHN can be seen in the Garis-garis Besar Haluan Negara (GBHN), which set its outline continuously over time. But in another perspective, NPL can also be understood from the background and the process of issuing official formulations, contained in the GBHN. Along with the coming era of reform, GBHN is not known anymore. Instead, to find out the PHN from a formal perspective, it can be seen Law No. 17 of 2007 on the National Long Term Development Plan (Indonesian: Rencana Pembangunan Jangka Panjang Nasional or RPJP) of the Year 2005-2025, which by the law is summarized in the RPJP 2005-2025.

According to the 2005-2025 National Long-Term Development Plan (Indonesian: RPJPN), legal development is carried out through: "Reform of legal materials, with due regard to the diversity of prevailing legal arrangements and the effects of globalization, as an effort to increase legal certainty and protection, law enforcement and human rights human rights, legal awareness and legal services of justice and truth, order and prosperity in the framework of a more orderly, orderly, smooth, and globally competitive state "(Law No. 17, 2007). In other words, such a statement comes up with a slight change of words as follows: "The development of the law is carried out through legal reform, with due regard to the diversity of the prevailing legal order and the influence of globalization in an effort to increase legal certainty and protection, law enforcement and human rights human, legal awareness, and legal services with justice and truth, order and prosperity in the framework of a more orderly and orderly state so that, the implementation of national development will be more smoothly "(Ibid). In another section there is also a statement which reads: "The development of legal material is directed to continue the renewal of legal products to replace the legislation of colonial inheritance, which reflects the social 
values and interests of the Indonesian people....." (Ibid).

The only hope of legal reform in the sense of law reform is in the hands of the judges, because according to Article 5 paragraph (1) of Law Number 48 Year 2009 the judge is given the absolute authority to explore, follow and understand the legal values and sense of justice who live in society. Thus the judges can do ijtihad reform of law, based on the values and sense of justice developed in society. In practice, legal reform based on the National Legal Policies (NLP) is also evident from some revised legislation, including the Law on Judicial Power and several laws, on the courts within the General Courts, Religious Courts and Administrative Courts Country.

\section{Legal Reform of the Islamic Law}

According to Islamic Encyclopedia (Nina M. Armando, 2005: 32), since the beginning of its history Islam has had a tradition of reform (tajdid). This is because tajdid gets justification and validation from the Qur'an, and the hadith of the Prophet Muhammad narrated by Abu Dawud: "Allah will send this Ummah (Muslims), at the beginning of every century that will renew his religious affairs "(QS.7 (al-'Araf): 170 and QS.11 (Hud): 117). Islamic law in writing as a concrete rule (though not using the format of legislation), is contained in the books of jurisprudence. That is why reform of law in Islam is often identified, with the fiqh reform.

According to the history of madhhab Syafi, actually renewal of fiqh in the sense of change of jurisprudence is not new. This is illustrated by the qaul qadim and qaul jaded, in this school. Wahbah Zuhaili mentions the existence of five methods of renewal of jurisprudence, which has been running among Muslims. These methods are:

- Salafi Method. This method invites the people to return to the fiqh of the Salaf, ie the Companions and the Tabi in, and break away from the four schools. Pioneers of this movement include Muhammad Yusuf Musa, Syakih Muhammad al-Muntashir al-Kattani, and Ruwwas Qala'ji. The group of adherents of this method, invites to re-learn the ijtihad of the Companions, especially Umar bin Khattab.

- Intiqa'i or Ghawgha'i Method. Wahbah Zuhaili defines this method as a method of choosing, what feels good according to personal desires and lust. The overview of the method is cursory and not exhaustive, whereas adherents of this method have no requirement as a mujtahid. Unfortunately Wahbah Zuhaili, does not show examples of ijtihad adherents of this method.

- Udwani Method. This method is hostile to the firmness of Islamic jurisprudence, as a whole and ignores the legacy of the legacy of fiqh that is very rich and has been recognized by legal experts and legal practitioners in the contemporary world. Abandoning Islamic fiqih is a destructive method, as it places the syar'i nash in the last position, and takes what is considered to have the maslahat, based on lust.

- The Taqribi Method. This method tries to bring jurisprudence to the positive law, as if the positive law is sacred and high, while the Islamic jurisprudence is underneath. Adherents of this method attempt to do takwil of nash sharia and contrary to the nash of goals. This is a reversal of reality, because the positive law establishes the reality of social relationships to achieve stability regardless of morality and religion.

- Method of Mu'tadil Mutawazin or Wasathi. This method is also called a moderate, balanced, or mid-way method. This method can be accepted syari 'as well as reason, because first, this method keep everything that has been fixed in the shari'ah; secondly, this method looks at developmental demands on the basis of mashlahah 
mursalah, including the general urf, as a form of practicing the spirit of shari'ah without "crashing the nash". This method is used by the friends, tabi'in, and the imams of the school in every time and time. This method seeks to realize authenticity and modernity at once.

This method also brings together two things: first, sticking to the texts, and secondly, maintaining and reconciling the benefits and needs after deep understanding of the texts and explaining the illat. Wahbah Zuhaili, pointed to an example in the banking world with the emergence of Islamic banks, which eventually evolved throughout the world (Wahbah Zuhaili and Jamal Athiyah, 2002: 129).

In the twentieth century, more and more reforms of Islamic legal thought were made by Muslim scholars, as well as by Orientals scholars. They actually contributed a lot in the development of Islamic legal studies conducted by figures such as Goldziher, Joseph Shacht, N. J. Coulson and Others. It's just that Orientals studies do not get a good reputation, among the Muslims for various reasons (Syamsul Anwar, 2002: 149).

Fazlur Rahman, for example, offers a specific moral and legal ideal in the meaning of texts and the early division of Islamic tradition; Muhammad Arkoun offers a re-understanding of the Islamic tradition and he also questioned the validity of the restoration of fiqh theories that have been composed several centuries ago, that are irrelevant to the present (A. Khudori Sholeh, 2003: 4). Sensing the theoretical framework of Wael B. Hallaq in the History of Methodology of Fiqh (Ushul Fiqh), Amin Abdullah outlines the methodological paradigm of fiqh usage, into three categories: literalistic, utilitarianistic and liberalistic-phenomenologic fiqh paradigms. Named the literalistic paradigm, because of the dominant discussion of the text. Al-Syafi'i's Al-Risalah is considered the first pioneer of figh proposals, the writing of a deductive theology followed by ushul martakallimun scholars (Shafi'iyah, Malikiyah, Hanabilah and Mu'tazilah) (Ibid). After more than five centuries (from the 2nd century H-7 H), it was only improved by the emergence of al-Syatibi (1388 AD), which added the theory of maqashid al-syari'ah which refers to God's most fundamental purpose, as the maker of the law (Ibid). Meanwhile the question of how the sacred text can be understood and then operated in the context of the modern world, which is no longer the same as the context of the Prophet's time. Such statements, according to some experts such as Muhammad Iqbal, Mahmud Muhammad Taha, Abdullah Ahmed al-Na'im, Muhammad Said Ashmawi, Fazlur Rahman and Muhammad Syahrur, cannot be solved completely based on the classical principles of maslahah above. They assume that maslahah principle is no longer sufficient, to make Islamic law relevant in the modern world. Weil B. Hallaq calls this group the flow of religious liberalism because; it tends to stand on the paradigm, that is detached from the classical paradigm (Amin Abdullah, 2002; 118-123).

\section{Theory and Status of the Fatwa Law}

\section{Terminology of Fatwa}

According to M. Atho Mudzhar, terminology of the fatwa can be interpreted, as "an Islamic legal opinion given by an Islamic jurist in answer to a question". (Muhammad Atho Mudzhar, 1993: 2). In line with the opinion of M. Atho Mudzhar above, in the Encyclopedia of Islam the fatwa constraints are expressed, as "the answer to a question of legal stipulation based on the results of ijtihad, on an issue that is not yet clear" (Ahmad Fatoni 2000: 40).

The study of fatwas is often discussed by ulama ushul fiqhin his books. According to ulama ushul fiqh, fatwa is the opinion expressed by a mujtahid or faqih, as the answer of the proposed fatwa in a case that is not binding. The party requesting the fatwa may be a private person, an institution, or a community group. The fatwa proposed by the Mujtahid or faqih is not 
necessarily, followed by the person who asks for a fatwa and therefore, the fatwa has no binding power (Cik Hasan Bisri, 2003: 39). In terms of legal products, there is a difference between mujtahid and mufti. The Mujtahids seek to decipher the laws of the Qur'an and al-Sunnah in various cases, whether requested by others or not. While, mufti only issues the fatwa if requested and the problem posed to him is a question that can be answered, according to the knowledge he has. Therefore, mufti in the face of legal issues must really know, in detail about the case in question, consider the welfare of the fatwa, the surrounding environment and the objectives to be achieved from the fatwa (Abu Zahrah, Muhammad, T. T.: 401).

\section{Term of Mufti}

According to Imam Ahmad bin Hanbal (164-241H / 750-855M), the requirement to be a mufti is: (1) Intent solely seeking the pleasure of Allah; (2) authoritative, patient, able to withstand anger and not arrogant (humble); (3) Knowledgeable and broad-minded, so he is steadfast in bringing forth truth; (4) To be adequate, not to rely on the necessities of life to others, so that he is not affected by the giving or gifts of others in making decisions; (5) Knowing the sciences of society, because a decree of law, which is decided must be based on the benefit and not cause the community's conscience (Ahmad Fatoni, Op.Cit: 42-43).

The ulama ushul fiqh expressed the requirements that must be met in a mufti, for the fatwa can be justified. The requirements are baligh (Islamic sexual jurisprudence), intelligent, independent, fair, and qualify as a mujtahid or have the scientific capacity to issue a fatwa. Under this requirement, a mufti does not have to be a man; a woman may be a mufti of origin, to meet the above requirements. The meaning of just, according to al-Gazali, is a person who istiqomah in his religion and maintain his personal honor. This requirement is very necessary, because mufti is a role model for society, both in terms of fatwa issued and in terms of personality. For terms of mufti, ulama ushul fiqh also put forward the implications of this condition. According to them, there are three things that must be considered by the mufti in relation to the fair terms (Wahbah Zuhaili, 1986: 168):

- Each fatwa must always be based on the proposition. If the fatwa was taken from the opinion of the early Mujtahids, then he should choose the strongest opinion of his theorem and more oriented to the benefit;

- If the mufti has the knowledge capacity to distribute the law, then he should seek to extract the law from the texts by considering the various realities;

- The fatwa does not follow the will of the mustafti, but consider and follow the will of the theorem and the benefit of mankind.

\section{Legal Status of Fatwa}

Therefore, it can be said that the fatwa institution is an authoritative institution, because the institution accommodates the elite group of influential clerics in the community, so that, the fatwa issued will also have a widespread impact among the people. The power of the ulama as an elite group, stems from several factors, among others: First, because of the depth and breadth of knowledge possessed by scholars especially religious knowledge, so they are considered more competent to talk about the issues of religious (Islamic) law; Secondly, scholars usually have broad followers and influence in society, so their opinions are often used in religious affairs; Thirdly, because of its widespread authority and influence, the ulama also became respected and respected informal leaders and leaders in the community. 
However, the fatwa of a mufti is not binding to mustafti, that is, if a person asks a fatwa and mufti to provide a legal solution, then mustafti may accept and practice the fatwa, and may also refuse and not practice it. This is different from the legal decision issued by the judge. If he is incracht, has permanent legal force, the judge's verdict is binding and must be carried out by the parties concerned. Besides, the fatwa can be given to anyone indiscriminately, while the judge only gives a decision on the territory of his power (Mukhtar Yahya and Fatchurrahman, 1986: 407).

While the development of figh is segmented in some madhhab, then mufti also changed. Mufti is no longer required as an absolute mujtahid, but turns into a mufti in a madhhab or mufti that only controls a madhhab. The emergence of many mufti resulted in the variety of fatwas issued by mufti, so that often occurs among lay people find more than one fatwa for a similar problem.

If the mufti's opinion is the same, or at least one direction, then it can show that it is the only solution to the problem. But if there are many fatwas for one problem, then in this case there are three alternative opinions: First, the layman or mustafti may choose one of the fatwas and ignore the other. For all mufti are assumed to do the same effort, to establish (mengistinbath) a law. The mufti work within relative, relative and truth (dzan) realms. Secondly, the layman or mustafti does not have the freedom to choose, but must choose the fatwa which is considered the most fair, the most trusted and the most expert in the field of Islamic law. Thirdly, the layman or mustafti is required to accept a prohibiting opinion, rather than allow or advocate, since such is considered more cautious (Wael B. Hallaq, 2000: 183-184).

Among the three options was the first opinion of the most widely used, because mustafti has enough space to determine, which fatwa is more suited for himself in accordance with his knowledge and belief. In some Islamic countries today, mufti occupies an important position and is one of the official institutions that take care of various problems of Muslims. For example, in Egypt, Saudi Arabia, Syria and Morocco, Mufti as one religious office is no longer bound by one of the schools, but it is more comprehensive, considering the various opinions of schools, according to the circumstances of the people. In addition, mufti is also bound by the applicable legislation in his country (Ahmad Fatoni, Op.Cit: 327).

\section{The Determination Method of Fatwa Majelis Tarjih Muhammadiyah}

The Muhammadiyah is one of the oldest Islamic organizations (mass organizations) of Islam in Indonesia. This organization was originally founded by K. H. Ahmad Dahlan on 8 Dhulhijjah 1330 H, coinciding with November 18, 1912, in Yogyakarta. As a community organization, he takes care of various community service businesses such as education, proselytizing, economics, healthcare, orphanages, etc., whose numbers are increasing every year. It also has various autonomous organizations, Assemblies, and others related to the aspirations of Muhammadiyah (Rifyal, 1999,: 89).

In terms of its name the Muhammadiyah organization seems very different from other Islamic organizations, even such names tend to be considered taboo by most traditional scholars, since the term Muhammadiyah implies "the teachings of Muhammad" or "the followers of Muhammad's teachings", a term deemed forbidden, because the religion of Islam is not named with the name of the carrier. In addition the term Muhammadiyah is also seen as a translation of Mohammedanism (the teachings of Muhammad), a term used by orientalists as a title for religion brought by Muhammad (Islam), According to (H. A. R. Gibb, 1966: 1-2).

The Muhammadiyah argues that, the use of this term has a high philosophical purpose, which implies the desire and aspiration of Muhammadiyah, to return to the pure teachings of the Prophet Muhammad (peace be upon him), received from Allah. On the other hand, the use of the term Muhammadiyah is also intended as a differentiator from some other 
Muslims, who are more adhering to certain schools of teaching, such as Shafi'iyah, Hanafiah, Malikiah, Hanabilah, Naqsabandiah, Sanusiah, etc., rather than directly to the teachings of the Prophet Muhammad.

The teachings brought by the Prophet Muhammad saw that, this can be seen from the seven principal thoughts that became the core of Muhammadiyah's Basic Articles of Muqadimah. These ideas are extracted from the thoughts and ideals of K. H. Ahmad Dahlan (founder of Muhammadiyah), by Ki Bagus Hadikusumo (Chairman of PP Muhammadiyah period 1942-1953, TT: 447-470):

- Human life must be based, on tauhid (crowding God): God-godliness, worship and submission and obedience to God.

- Life is a society, only the true Law of God is the only one who can be made joint, to form the main person and set the order of life together in society towards the ultimate happy and prosperous life, in the world and the hereafter.

- Striving to uphold and uphold the religion of Islam to realize the true Islamic society, is mandatory, as worship to God, ihsan and ishlah to human / society.

- The struggle to uphold and uphold the religion of Islam so that, the realization of a true Islamic society, will only be able to succeed by following the trail (ittiba') the struggle of the Prophet, especially the struggle of the Holy Prophet Muhammad.

- The struggle to realize the main idea is only to be executed, with the best and succeed, if by way of organization. Organization is the only means or means of struggle as well as possible.

The main points of thought / principles / stances as described and explained in advance, are those who can realize the beliefs and ideals of life especially to achieve the goals that become his goal, is the realization of a just and prosperous society born inner who blessed by Allah, is the true Islamic society. The fifth point clearly indicates the desire to follow in the footsteps of the prophets, especially the Grand Prophet Muhammad, and not to follow in the footsteps of those who claim to be followers of the Prophet or those who accept the understanding of the Prophet like the clergy, the madhhab and other priests. Following the Prophet is one of the core thoughts of Muhammadiyah that can be seen from the decision of Lajnah Tarjih.

The Muhammadiyah mentioned that, this organization (in the early 1990s) had 6,177 pre-school, elementary, middle and high school institutions. Beyond that, Muhammadiyah also has 831 public service agencies that include hospitals, clinics, pharmacies, orphanages, and others (PP Muhammadiyah, TT: 14-15). In addition Muhammadiyah also has 9 Councils, consisting of: Majelis Tarjih, Majelis Tabligh, Majelis Pendidikan Tinggi, Majelis Pustaka, Majelis pendidikan dasar dan menengah, Majelis Pembina Kesehatan, Majelis Pembina Kesejahteraan sosial, Majelis Ekonomi, dan Majelis Wakap \& Kehartabendaan (Report Muhammadiyah Central Leaders Period 1990 - 1995: 2).

One of the nine existing Assemblies is the Majelis Tarjih with its Lajnah Tarjih, who holds meetings and produces decisions from time to time. The Lajnah Tarjih is literally the Strongest Questioning Committee. Organizationally, it is a meeting of deliberations, under the Majelis Tarjih Pusat Muhammadiyah, with the task of assisting the association in decision-making and decision-making. In everyday conversations, the terms Lajnah and Majlis are often mixed up, when in fact they have different meanings and positions. The Majlis Tarjih is an institution under Muhammadiyah Central Leadership, while Lajnah Tarjih is a committee meeting, on the issues to be addressed (the 
strongest opinions of the propositions). The Lajnah concentrated on doing research in the field of religious knowledge and Islamic law, so as to obtain its purity. This is in line with the spirit of Muhammadiyah, that seeks to understand and practice the teachings of Islam purely (Ibid).

The Tarjih Council is derived from the great idea of K. H. Mas Mansur at the Muhammadiyah Congress XVI in Pekalongan, in 1927. This figure proposed that in the Muhammadiyah Union established three Majlis, namely are Majelis Tasyri, Majelis Tanfidz, Majelis Taftisy (M. Yunus Anis, March II 1972 / Shafar I, 1932): 3). This proposal was accepted unanimously by Congress. To make it happen, a team of formulation members consisting of: (1) K. H. Mas Mansyur from Surabaya, (2) A. R. Sutan Mansur, from Maninjau, (3) H. Muchtar, from Yogyakarta, (4) H. A. Mu'thi from Kudus, (5) Kartosudarmo from Jakarta (6) Muh, Kusni, and (7) M. Yunus Anis, from Yogyakarta. (H. D. Q. Muchtar, 1985,: 11-12). A year later, at the 17th Muhammadiyah Congress in Yogyakarta, a Tasyri council was formed under the name of the Majelis Tarjih, K. H. Mas Mansur himself was elected as its chairman (Ibid).

Officially, the Muhammadiyah Tarjih Assembly was established, based on the decision of the 16th Congress in Pekalongan in 1927, namely the period of K. H. Ibrahim, who became chairman of the second the Hoofdbestuur Muhammadiyah after K. H. Ahmad Dahlan. As mentioned earlier in the description that, the proposed formation of the Majelis originated from and on the initiative of a prominent scholar from Surabaya, namely K. H. Mas Mansur, at that time he became consul Hoofdbestuur Muhammadiyah area of Surabaya. The idea of the founding of this Majelis had previously developed in Surabaya in the 15th Congress of 1926. So, about 15 years from standing Muhammadiyah, this Majelis Tarjih was just established.

Although the Majelis Tarjih has not officially established in the first 15 years of Muhammadiyah's birth, this does not mean that, at such times the organization is deserted from the masticating efforts, as an Islamic movement that has the purpose to perform tajdid (reform) in religious life, since the beginning of Muhammadiyah has been trying to continuously conduct studies and research on religious issues, especially disputed among the community. It is just that, the review and pouring of these religious issues has not been formally done, during the Congress, as it was done after the founding of the Majelis Tarjih, but only the informal activities in the Muhammadiyah leaders' respective teachings, in their respective regions. Generally speaking the birth of the Majelis Tarjih Muhammadiyah is motivated by two factors; they are internal factors and external factors.

\section{Internal Factor}

Internal factor is a developing condition within Muhammadiyah, which is, with the emergence of new problems caused by the expansion and progress achieved Muhammadiyah. The development of Muhammadiyah was initially so rapid, both in terms of expansion of organizational areas, membership, and in terms of business charity. As in education, social services, da'wah, and others. The large number of new members, who, of course, originally came from traditional Islamic charity communities, will bring problems in religious practice, causing strife with fellow members who have long since abandoned traditional religious practices. This situation requires the birth of a body or Assembly which will conduct for disputed matters to determine the opinion that is considered the most powerful to be practiced, and the weak opinion that must be abandoned, and ultimately obtained uniformity in religious practices among members of Muhammadiyah.

\section{External Factor}

External factors are factors caused by Muhammadiyah friction with other groups of society, both with different 
Muslim societies as well as with Christians and the West in general. The Muhammadiyah friction with other Islamic groups created khilafiyah-khilafiyah, in the matter of understanding and religious practice, especially those viewed as furu iyah, such as problems, recitation of ushali (praying intent), basmallah reading before Fatihah and letters in prayer, qunut problem in shubuh prayer, problem adzan twice on Friday prayers, tahlil problems, and others. The Muhammadiyah's friction with the modern world, also spawned many new problems that need to be affirmed in its legal provisions, such as the problems of women working as employees in companies, blood transfusion problems, family planning issues, banking problems, insurance issues, and so on. The above problems demand the immediate establishment of an institution or assembly or body authorized to enact Islamic laws, or to pursue legal provisions that are still disputed in response to the problems faced. (Hoofdbestuur (PP) Muhammadiyah pada tahun 1935, Himpunan Putusan Tarjih, PP Muhammadiyah, TT: 371$)$.

\section{Position, Function and Authority of the Majelis Tarjih}

Initially Majelis Tarjih was an autonomous clerical institution and was based only at the central level. The function of this institution is to ascertain the provisions of Islamic law on disputed issues among the people, both those concerning traditional jurisprudence and Islamic laws in a broad sense. At that time, there were concerns among Muhammadiyah figures that these problems would enter into this organization and affect its journey if it were not immediately discussed in deliberations or scientific meetings involving intellectuals and the ulama (Ibid).

On the later development of the Majelis Tarjih became the Assistant the Badan Pembantu Pimpinan Persyarikatan, who in carrying out their duties are responsible to the pimpinan persyarikatan, at each level. The existence of the Majelis Tarjih is an important part of Muhammadiyah. The importance of this Majelis Tarjih can be seen from the stand, and the main functions and tasks assigned to it. In terms of kedududkannya, Majelis Tarjih positioned as a helper Leadership of the Union at each level, ie, from the level of the Central Leadership to the level of Regional Leadership. This means that the Majelis Tarjih is located and becomes the Chairman of the Association of Persyarikatan from the level of Region, Region, to the Center. The function of the Majelis Tarjihy is as stated in the Qaeda of the Majelis Tarjih as follows (PP Muhammadiyah, 1993: 116)

- The Majelis Tarjih Pusat has the function of assisting the Pimpinan Pusat Muhammadiyah in executing the decree of association related to the Tarjih Assembly;

- The Regional Tarjih Council has the function of assisting the Chairman of the Pimpinan Persyarikatan Wilayah Muhammadiyah in implementing the approval of the association related to the Tarjih Council;

- The Regional Tarjih Council has the function of assisting the Regional Leaders of Muhammadiyah in implementing the decree of association related to the task of the Majelis Tarjih.

The tasks to be undertaken by the Majelis Tarjih is, as stated in the Surat Keputusan Pimpinan Pusat Muhammadiyah Number 74 / SK / I-A / 8.c / 1993 about the Qaidah Majelis Tarjih Muhammadiyah. Mentioned that the main task of the Majelis Tarjih is (Acceptance of Muhammadiyah, 1994: 13):

\section{Manhaj Majelis Tarjih in Decision Making}

The Manhaj (methodology) of Islamic thought in the Muhammadiyah, on the one hand, is seen as a necessity along with the intensity and extensiveness of various life developments. While on the other hand, is the recognition of the 
relative nature of historical products, especially those involving manhaj. The Manhaj is a methodological framework in formulating the problem of thought and its settlement procedures, which contains basic assumptions, development principles, methodology and operationalization. This Manhaj is comprehensive, flexible, functional, tolerant, open, and responsive to scientific and societal development.

The Muhammadiyah as a socio-cultural religious movement, in its historical dynamics always try to respond to various development of life, by always referring to the teachings of Islam (al-rujû'ila al-Qur'ân wa al-Sunnat almaqbûllat). On the one hand history has always spawned various problems and on the other hand, Islam has provided normative references to these various problems. Orientation to the divine dimension is what distinguishes Muhammadiyah from other socio-cultural movements, both in formulating the problem, explaining it and in preparing the operational framework of its solution. This orientation requires Muhammadiyah to produce thought, review and reconstruct its manhaj.

In general, it can be said that, the legal decision-making process in the Majelis Tarjih Muhammadiyah is done not by individual (individual), but rather determined on the basis of the results of mutual consultation and agreement. This kind of legal decision-making process among ushul scholars is known as ijtihad jama i. Team Tarjih PP Muhammadiyah itself formulates the understanding of ijtihad jama'i as follows (Team PP Muhammadiyah, 1996: 244): Ijtihad jama'i is a collective ijtihad, a group of experts in Islamic law who seek to obtain the law of something or some issues of Islamic law. According to Muhammadiyah, this kind of ijtihad was done in the days of the Prophet's companions. The most obvious example is the deliberation of Abu Bakr's election as khalifah, the collection of the Qur'anic texts of the caliphate of Abu Bakr al-Siddiq ra., And the writing of his mushaf, at the time of Caliph Uthman ibn Affan (Hasbi Ash-Shiddieqy, 1997: 165). Seen in terms of the agreement reached, among the mujtahid friends who existed at that time, these three decisions are called ijma ', and the attempt to arrive at that decision is called Ijtihad jama' (Ibid).

\section{METHODS, APPROACHES AND TECHNIQUES}

- Method: Bayânî (semantics), a method that uses a language approach; Ta lîlî (rationalistic) is a method of lawsetting, using the reasoning approach (ratio); Istislâhî (philosophical) is a method of law-setting that uses philosophical approach.

- Approach: the approaches used in establishing the law of ijtihadiah are: al-Tafsîr al-ijtimâ $\hat{\imath}$ al-ma âsir (hermeunetik); al-Tarîkhiyat (historical approach); al-Sûsiulûjiyat (Sociological Approach); and al-Antrufûlujiyat (Anthropological Approach);

- Techniques: The techniques used in establishing the law are: (1) Ijmak; (2) Qiyas; (3) Mashâlih Mursalat; (4) 'Uruf.

\section{Ta`arudh al-Adillat}

- Ta`arudh al-adillat is a contradiction of several propositions;

- If ta arudh happens then it is solved in the following order of ways: al-Jam 'u waal-tawfiq, i.e. the attitude of accepting all the propositions even though the dhahiriyah seems contradictory. While, on the plains of its implementation is given freedom to choose; al-Tarjih, ie to choose a stronger proposition to live out and leave a weaker theorem; al-Naskh, that is to apply the arguments that appear more recently; and al-Tawaqquf, stopping research on the propositions used by finding new propositions. 


\section{Tarjih Method on Nash}

The pouring of the nash is seen in several ways: the point of sanad: the quality and quantity of the rawi; shape and nature of transmission; and shighat al-tahammul wa al-ada '; aspect of matan: matan using shighat nahyu more rajih than shighat amar; matan using khash shighat is more rajih than shighat 'am; aspects of legal material and other external aspects (Ibid).

From the above description, it seems that, the Majelis Tarjih Muhammadiyah has been and is still trying continuously, to look for a more comprehensive pattern in establishing the laws it bore. In reality, however, the Majelis Tarjih still has to recognize and use the istinbath methods, that have long been known among the scholars of $u s h u l$ fiqih.

\section{Sources of the Islamic Law According to the Majelis Tarjih}

According to the Majelis Tarjih Muhammadiyah the source of Islamic law is in principle to only two, namely the Qur'an and al-Hadîts al-Shahîhat. In the case of facing new problems, as long as the matter is not related to the mahdhah worship, and there are no shari'ah texts, in the Qur'an or in al-Hadîts, it is permissible to do ijtihad and istinbath from nash through the illat equation. This statement shows that for Muhammadiyah ijtihad is not a source of law, but as a method of law enforcement in Islam. Furthermore, the process of law enforcement according to Majelis Tarjih Muhammadiyah is as follows (Adijani al-Alabij, 1989: 55):

- Directly propose the argument to the Qur'an and al-Sunnat;

- $\quad$ Using the ushul rules;

- Using sound reason judgment;

- $\quad$ Unbound to the istinbath system of any ulama / madhhab.

Although theoretically the Majelis Tarjih Assembly, in performing its istinbath is not tied to a particular school of thought, in practice they still consider the opinions of the earlier scholars. Even in terms of the name alone, "Tarjih", has indicated an attempt to choose one of two or several different opinions that of course have been there before (Ibid).

\section{Determination Method of the Fatwa Majelis Bahtsul Masa'il Nahdhatul Ulama (NU) Background of NU Establishment}

Nahdhatul Ulama (revival of the ulama) began to be established since 1926, precisely on January 31, 1926. Tokoh its founder and Chairman of the First is K. H. Hasyim Asy`ari. There are several factors that should be suspected to be the background of the birth of NU, among others:

- Traditional clerics at that time reacted against the Wahabi movement, which carried out the demolition of the sacred pilgrimage places in Saudi Arabia, they formed the Hijaz Committee chaired by K. H. Hashim Asy`ari to convey a petition to King Ibn Sa`ud to stop the demolition;

- The establishment of NU is also a form of reaction to the renewal movement in the homeland that has been considered troubling society and traditional scholars;

- As a form of effort to maintain the practice of Islamic tradition, which has been inherited by the ulama from generation to generation. 


\section{The purpose of NU}

The purpose of the founding of NU as stated in the Qanun Asasi is (Congress of NU XXVIII, 1989: Chapter IV), they are:

- Hold fast the teachings of Islamic scholars of fiqh scholars, by holding to one of the four schools of thought (Hanafi, Maliki, Shafii or Hanbali);

- Maintain and practice the teachings of Islam according to Ahlu Sunnah wal jama ah (Qanun Asasi and Qanun Dakhili Khithah Jam iyah Nahdhatul Ulama (NU), 1926); to achieve these objectives, NU undertakes the following efforts (Extra Bigvoegsel der Javasche Courant: 2-3; Solichin Salam: 67-68):

- Make connections among scholars, who adhere to the teachings of the Imam of the madhhab (one of the four schools);

- Examine the books to be taught to know whether from the books of Ahlu Sunna or not;

- Broadcasting the teachings of Islam by adhering to the teachings of Islamic scholars;

- Increasing Islamic-based madrassas / schools;

- $\quad$ Fostering mosques, suras, lodges, orphanages and the poor and needy;

- Establish agencies to promote agriculture, commerce and companies that are not prohibited by shara.

\section{STATUS OF THE ULAMA}

In Jam'iyah NU the scholars have a high and privileged position, namely: (Ibid)

- The Ulama as a chain of bearers of Islam according to the school of Ahlu Sunnah wal jama 'ah;

- Scholars as managers, controllers, supervisors and mentors of the organization.

- $\quad$ The Ulama as the key holder and the doors of religious knowledge.

\section{THE IJTIHAD METHODOLOGY OF THE MAJELIS BAHTSUL MASA'IL NU}

The legal decision-making system in the NU's bahtsul masa'il was set in the National Congress (Indonesian: Musyawarah Nasional) of Ulama NU in Bandar Lampung on 16-20 Rajab 1412 H. coinciding with 21-25 January 1992 and coinciding with the date of 16-20 Rajab $1412 \mathrm{H}$ (Jaih Mubarok, 2002: 179). NU Fatwa Institution is named Majelis Bahtsul Masa'il. The source of the Law used is the Kutub al-Mu'tabarah, the books that have been used as reference standards for the taking of law and aqidah, based on the flow of ahlu sunnah wal jama ah, compiled by the imams and scholars of the schools, especially the scholars of Shafi'iyah Results of NU XXVII Congress, January 21-25: 1992).

The methodology of ijtihad Majlis Bahtsul Masa'il NU in general there are two forms, namely: (1) the Madhab on a qauli basis; (2) Being practiced in manhajiWhile the procedure of determining the law, is as follows, Jaih Mubarok, Op.Cit: 180-181):

- If the answer to the proposed / discussed problem has been found in the book and there is only one qaul / face, then the legal provisions are established through the qaul / face of the ulama; 
- If the answer to the problem is found more than one qaul / face then done taqrir jamai to choose one qaul / face;

- If in the polar al-mu tabarah that, there is no answer to the problem proposed / discussed, then the method ilhaqul masa'il bi nadza'iriha in jama $i$.

- If not found qaul / face of scholars and cannot be done ilhaq then, it is done istinbath in jama $i$ way madhab by manhaji by the experts.

\section{The Taqrir procedure jama $\mathbf{i}$}

If the answer to the problem discussed found some qaul / face, then attempt to choose one of qaul / face;

The selection is done by:

- $\quad$ Choose an opinion agreed upon by al-Shaykhan (Imam Nawawi and Imam Rafi)

- Selects the opinion put forward by Imam Nawawi alone;

- $\quad$ Select the opinion expressed by Imam Rafi $i$ only;

- Selecting opinions supported by the majority of ulama;

- Select the opinion put forward by the cleverest scholars;

- Selects the opinions expressed by the waraulama.

\section{The Ilhaq Procedure}

The Ilhaqul masa'il bi nadha'iriha, it means to equate the law of a case, which has no qaul / face with the existing law case qaul / face because of the equation 'illat law. Thus, the procedure of ilhaq uses qiyas and analogy procedures, ie by considering mulhaq bih, mulhaq ilaih and wajhul ilhaq. The difference with qiyas, in qiyas are used as ashal is nash, while in ilhaq is used ashal is the face / qaul. Manhaji's Manuscripts Procedure: If the law of a particular case or problem is not found in the answer of the mu 'tabarah, and it is also impossible to do ilhaq in the absence of equality of the 'illat law, istinbath jama $i$ is done by using qawa id ushuliyah and qawa`id fiqhiyah commonly used by imams / ulama of madhhab (Ibid).

\section{CONCLUSIONS}

The fatwa has a very urgent role in the reform of zakat law in Indonesia, because although the provisions of zakat law are set in detail in the texts of the Qur'an and al-Sunnah, but in line with the ever-changing social life, the demand for renewal of zakat law is inevitable from time to time. This, is in accordance with the rule which states: "Nash (al-Qur'an and al-Hadith) has ceased to fall, while events / problems in society will not cease" (النصوص مناهية و الو اقائع غير مناهية). To answer new issues about zakat can only be done through a fatwa established, by scholars or institutions that are competent and reliable.

In essence a fatwa is a legal opinion submitted by ulama both individuals and groups, who are members of the fatwa institution, which is established through the process of ijtihad in response to the problems conveyed to him. The method of ijtihad conducted by the Muhammadiyah Tarjih Council tends to use the contextual interpretation of the texts and logical reasoning based on the consideration of benefit (al-burhani wa al-istishlahi). The method of ijtihad 
conducted by the Majelis Bahtsul Masa'il NU, to restore the problem to the opinions of earlier scholars in the books of mu'tabarah (ittiba al-madzhab) and in responding to new problems not found in the poles of al-mu'tabarah, the fatwa is established through ijtihad according to the method of ijtihad ulamaShafi iyah (ittiba al-manhaj). The method of ijtihad by the Council of Hisbah Persatuan Islam tends to return the question to the Qur'an and al-Sunnah, through textual interpretation (istidlal).

Many new legal thoughts are contained in the fatwas of the good zakat issued by: Majelis Tarjih Muhammadiyah, and Majelis Bahtsul Masa'il Nahdhatul Ulama (NU). These fatwas make an important contribution to the development of zakat law in Indonesia, both at the discourse level, at the application level The application of zakat law in Indonesian society is manifested as stated in the theory of legal authority, i.e. that if a Muslim has accepted Islam as his religion he will receive the authority of Islamic law to him. Therefore, sociologically, people who embrace Islam will accept the authority of Islamic law and obey in the implementation of Islamic law, including sharia about zakat. But this obedience will be different from each other because it depends on the level of piety of each. This is also in accordance with the theory of credo or creed which requires the implementation of Islamic law by those who have uttered the two kalimah shahada as a logical consequence of the pronunciation of his credo. In line with the non-territorial theory of Imam Shafi'i which states that a Muslim is forever bound to implement Islamic law wherever we are.

\section{REFERENCES}

1. Abbas Kararah, al-Dîn wa al-Zakât, Syirkah Fan al-Thiba`ah, Mesir, 1956.

2. Abdul Manan, Aspek-Aspek Pengubah Hukum, Prenada Media, Jakarta, 2005.

3. Abdul Wahab khalaf, al-Siyasah al-Syar`iyyah, Mathba`ah al-Taqaddum, al-Munirah, 1977.

4. Abi Abdillah Muhammad bin Abdi al-Rahmah, Rahmat al-Ummah fi Ikhtilaf al-A'immah, Dar al-Fikr, Beirut, 1996.

5. Abu Zahrah, Muhammad, Ushul Figh, Dar al-Fikr al-`Araby, Beirut, TT.

6. Adijani al-Alabij, Perwakafan Tanah di Indonesia, PT Rajawali Press, Jakarta, 1989.

7. Adijani al-Alabij, Perwakafan Tanah di Indonesia, PT Rajawali Press, Jakarta, 1989.

8. Ahmad Fatoni, Metode Istinbath al-Ahkam Fatwa MUI Jabar Tentang Sertifikasi Halal, Lemlit IAIN SGD, Bandung, 2000.

9. Amin Abdullah, "Paradigma Alternatif Pengembangan Ushul Fiqh dan Dampaknya pada Fiqh Kontemporer”, dalam Mazhab Jogja: MenggagasParadigmaUshulFiqhKontemporer, Ar-Ruz, 2002.

10. Berita Muhammadiyah No. 14/1990-1995, Ramadhan, 1414 H/ Pebruari 1994.

11. Cik Hasan Bisri, Model Penelitian Fiqih Jilid I, Prenada Media, Jakarta, 2003.

12. Dede Rosyada, Metode Kajian Hukum Dewan Hisbah Persis, Logos, Jakarta, 1999.

13. Depdiknas, Kamus Besar Bahasa Indonesia, Balai Pustaka, Jakarta, 2005.

14. Fathurrohman Djamil, Metode Ijtihad Majlis Tarjih Muhammadiyah, Logos, Jakarta 1993.

15. H. A. R. Gibb, Mohamedanism: An Historical Survey, Oxford University Press, New York, 1966.

16. H. D. Q. Muchtar, "Sejarah Majlis Tarjih” dalam Beberapa Aspek Pedoman Bertarjih, PP Pemuda Muhammadiyah, Jakarta, 1985.

17. Hasbi Ash-Shiddieqy, Pengantar Hukum Islam, PT Pustaka Rizki Putra, Semarang, 1997. 
18. Hasil Muktamar NU ke-XXVII di Bandar Lampung pada Tanggal 21-25 Januari Tahun 1992.

19. Hasil Munas Tarjih ke-25, "Manhaj Tarjih dan Pengembangan Pemikiran Islam”, dalam Suara Muhammadiyah, No. 15 Th ka-85.

20. Himpunan Putusan Tarjih, PP Muhammadiyah, Yogyakarta, TT.

21. Hoofdbestuur (PP) Muhammadiyah pada tahun 1935 mengumumkan dalam Suara Muhammadiyah No. 6/1936 tentang sebab pendirian Majlis Tarjih.

22. Jaih Mubarok, MetodologiljtihadHukumIslam, UII Press, Yogyakarta, 2002.

23. K. H. Hasjim Asj`ari, Ihya `Amal al-Fudhala, Muqadimah Anggaran Dasar Nahdhatul Ulama, Kendal, tanpa penerbit, 1989.

24. Khudori Sholeh (Ed), PemikiranIslamKontemporer, Jendela, Yogyakarta, 2003.

25. Laporan Pimpinan Pusat Muhammadiyah Periode 1990 - 1995 kepada Muktamar Muhammadiyah ke-43 di Banda Aceh.

26. M. Mahfudz MD, 2009, Pancasila sebagai Hasil Karya dan Milik Bersama, Dalam konggres Pancasila 2009, Sekjen dan Kepaniteraan MK, Jakarta, 2001.

27. M. Yunus Anis, “Asal Mula diadakan Majlis Tarjih” dalam Suara Muhammadiyah, No. 6 Tahun ke-52, (Maret II 1972/ Shafar I, 1932).

28. Margono Poespo Suwarno, Gerakan Islam Muhammadiyah, Penerbit Percetakan Persatuan, Yogyakarta, 1995.

29. Muhammad Atho Mudzhar, Fatwa-fatwa Majlis Ulama Indonesia: Sebuah Studi Tentang Pemikiran Hukum Islam di Indoensia 1975-1985, INIS, Jakarta,1993.

30. Mukhtar Yahya dan Fatchurrahman, Dasar-dasar Pembinaan Hukum Islam, Al-Ma`arif, Bandung, 1986.

31. Muktamar NU XXVIII di Yogyakarta pada tahun 1989. Bab IV (Tujuan), pasal 5 AD.

32. Nina M. Armando (et al), Ensiklopedia Islam, Ichtiar Baru Van Hoeve Jakarta, 2005.

33. PP Muhammadiyah, Majlis Tarjih, Qaidah Lajnah Tarjih Muhammadiyah, Penerbit Persatuan, Yogyakarta, 1977.

34. PP Muhammadiyah, Majlis Tarjih, Qaidah Majlis Tarjih Muhammadiyah, Penerbit Persatuan, Yogyakarta, 1993.

35. PP Muhammadiyah, Muhammadiyah Movement in Indonesia, Pimpinan Pusat Muhammadiyah, Jakarta, TT.

36. Qanun Asasi dan Qanun Dakhili Khithah Jam`iyah Nahdhatul Ulama (NU) 1926.

37. Rifyal Ka'bah, Hukum Islam di Indonesia, Universitas Yarsi, Jakarta, 1999.

38. Rifyal Ka'bah, Hukum Islam di Indonesia, Universitas Yasri, Jakarta, 1999.

39. Rusli Karim, Muhammadiyah dalam Kritik dan Komentar, Rajawali Press, Jakarta 1986.

40. Sahal Mahfudh, Nuansa Fiqih Sosial, LKIS, Yogyakarta, 2011.

41. Satjipto Rahardjo, Ilmu Hukum, Citra Aditya Bakti, Bandung, 2000.

42. Satjipto Rahardjo, Membangun dan Merombak Hukum Indonesia, Genta Publishing, Yogyakarta, 2009.

43. Shahih Bukhari juz I, Dar al-Fikr, Beirut,1981.

44. Soetandyo Wignjosoebroto, Pembaruan Hukum Masyarakat Indonesia Baru, dalam: Donny Donardono, "Wacana Pembaruan Hukum di Indonesia”, Ford Foundation \& HuMa, Jakarta, 2007. 
45. Syamsul Anwar, PengembanganMetodePenelitianHukumIslam, dalam Mazhab Jogja: MenggagasParadigmaUshulFiqh Kontemporer, Ar-Ruzz, Yogyakarta, 2002.

46. Tim PP Muhammadiyah, Tanya Jawab Agama II, Penerbit Suara Muhammadiyah, Yogyakarta, 1996.

47. Umar Hasyim, Muhammadiyah Jalan Lurus, PT. Bina Ilmu, Surabaya, TT.

48. Undang-Undang Nomor 17 Tahun 2007 Tentang Rencana Pembangunan Jangka Panjang Nasional Tahun 2005-2025.

49. UU No. 38 Th 1999, bagian Menimbang, Butir c.

50. Wael B. Hallaq, Sejarah Teori Hukum Islam, PT. Raja Grafindo Persada, Jakarta, 2000.

51. Wahbah Zuhaili dan Jamal Athiyah, Kontroversi Pembaruan Fiqih, Penerjemah: Ahmad Mulyadi, Erlangga, Jakarta, 2002.

52. Wahbah Zuhaili, Ushul al-Figh al-Islamy, Dar al-Fikr, Beirut, 1986.

53. Yusuf al-Qardhawiy, Min Ajli Sahwah Rasyidah: Tajdid al-Din wa Tanhad bi al-Dunya, Kairo: Dar al-Suruq, 2001. 